\title{
Evaluation of respiratory parameters in minimally processed lettuce grown under organic or conventional system
}

\author{
Júlio César Mello ${ }^{1}$, Renato Dietrich ${ }^{2}$, Luiz Fernando Dias Probst ${ }^{3}$, Edna Regina Amante ${ }^{4 *}$
}

\begin{abstract}
The increased preference for minimally processed vegetables has been attributed to the health benefits associated with fresh produce and the demand for ready-to-eat salads. In this paper, lettuce (Lactuca sativa L.) was evaluated for the effects of different cropping systems on the respiratory properties. Lettuce was packaged in low density polyethylene bags and stored in a refrigerator at $4{ }^{\circ} \mathrm{C}$. The concentration of carbon dioxide and oxygen inside the package was monitored during the storage at zero, three, six, eight, ten and twelve days by gas chromatography. Dry matter variation was measured gravimetrically up to day fourteen of storage. Values of respiratory rate for conventional lettuce increased from day 1 to 3 and remained low, while respiratory rate of the organic lettuce increased three-fold up to day 8, stabilizing at a high level. Variation in dry matter during storage also resulted from differences between the two cultivation systems. The highest content of dry matter was achieved by organic lettuce.
\end{abstract}

Key-words: Post harvest, storage, shelf life.

\section{RESUMO}

\section{Avaliação de parâmetros respiratórios em alface minimamente preocessada produzida em sistema orgânico ou convencional}

O aumento da preferência por hortaliças minimamente processada tem sido atribuído aos benefícios à saúde associado aos produtos frescos, bem como à demanda pelo consumo de salada pronta para o consumo. Neste trabalho, a alface americana (Lactuca sativa L.) foi avaliada quanto aos efeitos de diferentes sistemas de cultivo sobre as propriedades respiratórias. A alface foi acondicionada em sacos de polietileno de baixa densidade, conservada em refrigerador a $4{ }^{\circ} \mathrm{C}$. A concentração de dióxido de carbono e de oxigênio no interior das embalagens foi monitorada ao longo da conservação nos tempos 0 , 3, 6, 8, 10 e 12 dias por cromatografia gasosa e a variação da matéria seca foi avaliada por gravimetria até o décimo quarto dia de conservação. $O$ valor do padrão respiratório na alface convencional aumentou do primeiro ao terceiro dia e se manteve baixo, enquanto a orgânica aumentou a taxa respiratória até três vezes até o oitavo dia, estabilizando em alto nível. O sistema de cultivo também resultou em diferenças na variação da matéria seca durante o armazenamento. O mais elevado conteúdo de matéria seca foi atingido pela alface americana orgânica.

Palavras-chave: Pós-colheita, conservação, vida de prateleira.

Recebido para publicação em julho de 2009 e aprovado em julho de 2010

${ }^{1}$ Engenheiro-Agrônomo, MSc. Epagri - Empresa de Pesquisa Agropecuária de Santa Catarina, Rodovia Admar Gonzaga, 1.188, 88010-970, Florianópolis -SC, Brasil. jcmello@epagri.sc.gov.br

${ }^{2}$ Engenheiro-Agrônomo, MSc. Epagri - Empresa de Pesquisa Agropecuária de Santa Catarina, Rodovia Admar Gonzaga, 1.188, 88010-970, Florianópolis -SC, Brasil. rdietrich@epagri.sc.gov.br

${ }^{3}$ Químico, DS. Depto. de Química, UFSC, Centro de Ciências Físicas e Matemáticas, Campus Universitário, Bairro Trindade, 88040-900,Florianópolis- SC. Brasil. Email: probst@qmc.ufsc.br

4* Química Industrial, DS. Depto. de Ciência e Tecnologia de Alimentos, UFSC -, Rod. Admar Gonzaga, 1346, Itacorubi, 88034-001,,Florianópolis-SC, Brasil. eamante@cca.ufsc.br * Corresponding author 


\section{INTRODUCTION}

Organic agriculture is defined as the animal and vegetable origin food production system without the use of pesticides or synthetic chemical fertilisers or other contaminants, in the production systems. Such systems maintain a holistic emphasis, the maximization of social benefits, self-sustainability, reduction or exclusion of the use of non-renewable energy and profit dependence, and environmental protection by limiting the use of renewable natural and socially-available resources (IFOAM, 2002; Ngouajio et al., 2003; Cheftel, 2005). Organic agriculture and organic food processing follow norms and procedures established by the IFOAM (International Federation of Organic Movements) (Tamm, 2001).

The increasing preference for organic and minimallyprocessed vegetables has been attributed to the health benefits associated with fresh products as well as to consumer demand for ready-to-eat products (Baur et al., 2005). The aim of minimal processing is to provide fresh-like products with an extended shelf life while ensuring food safety and maintaining sound nutritional and sensorial qualities (Ahvenainen, 1996; Alzamora et al., 2000). Correct storage temperatures and packaging contribute to increase shelf life of minimally processed vegetables (Lee et al., 1991; Chitarra \& Chitarra, 2005). The respiration activity of minimally processed vegetables will increase 1.2 to 7.2 fold, or even more, depending on the procedure, cutting grade and temperature (Wiley, 1994; Mattos et al., 2008).

Mello et al. (2003) studied the effect of the conventional and organic cultivation system on the shelf life of minimally processed Iceberg lettuce shelf life. Organic lettuce was preferred by consumers, and presented longer self life compared to with the conventional lettuce.

Optimal-quality organic produce that achieves the desired textural properties, sensory shelf life, and nutritional content is the combined result of careful implementation of recommended production inputs and practices, careful handling at harvest, and appropriate postharvest handling and storage (Suslow, 2007). Iceberg lettuce is always consumed fresh in Brazilian salads in spite of its low content of vitamins, minerals and other nutrients. Its low caloric value allows it to fit in to almost all diets. Additionally, it is widely used in international food networks.

Despite the growing interest in organic production and minimally-processed vegetable consumption, very little research has been carried out comparing the effects of conventional and organic cultivation on minimallyprocessed vegetables. In this work, it is evaluated the effect of conventional and organic cultivation systems on respiratory parameters during storage of minimally processed Iceberg lettuce (Lactuca sativa L.).

\section{MATERIALS AND METHODS}

Iceberg lettuce was grown in four protected areas for each system (organic and conventional), with air temperature varying between $15^{\circ} \mathrm{C}$ and $25^{\circ} \mathrm{C}$. The cropping field was located in Florianópolis, State of Santa Catarina, Brazil, (27 $34^{\prime} \mathrm{S}$ and $48^{\circ} 30^{\prime} \mathrm{W}$ at 2.0 m.a.s.l.). Lettuce production was conducted according to organic and conventional practices.

\section{Organic cultivation}

The organic production of iceberg lettuce was carried out according to IBD (Biodinamic Institute) standards, following the norms of IFOAM, and are recognized by the Organic Produce Importers in Brazil. Sixty days before transplanting, soil fertility was amended with natural phosphate $\left(100 \mathrm{~g} \mathrm{~m}^{-2}\right)$, based on soil analysis. Thirty days before transplanting, bovine manure $\left(2 \mathrm{~kg} \mathrm{~m}^{-2}\right)$ was used as fertilizer. Two applications of liquid biofertilizer were carried out: the first at 32 days after transplanting, using $1000 \mathrm{~cm}^{3} \mathrm{~m}^{-2}$, and the second after 60 days, using the same rate. Microbiological analysis of pathogenic organisms in biofertilizer indicated no contamination, and its mean nitrogen content (dry base weight) was $48.5 \mathrm{~g} \mathrm{~kg}^{-1}$. Seedlings were transplanted at the four-leaf-stage on fortyfour days after plant emergence. Weeding was carried out by hand-hoeing.

\section{Conventional cultivation}

Conventional lettuce production was conducted according to recommendations of the Agricultural Extension Service of the State of Santa Catarina (EPAGRI, 1997). Thirty days before transplantingng, $2 \mathrm{~kg}$ of poultry litter (2.5\% of total nitrogen, dry matter basis) was applied per square meter. Fourteen days before transplanting, inorganic fertilization with $150 \mathrm{~g} \mathrm{~m}^{-2}$ of a 5-20-10 formula (5\% nitrogen, $20 \%$ phosphorus, and $10 \%$ potassium) was applied. A single transplanting was carried out 44 days after planting, at the four-leaf-stage. Weeding was carried out by hand-hoeing.

During the vegetative cycle, two side dressing fertilizations of calcium and nitrogen were applied. In the first, $60 \mathrm{~g} \mathrm{~m}^{-2}$ of calcium nitrate was applied 32 days after transplanting, and in the second, $75 \mathrm{~g} \mathrm{~m}^{-2}$ of calcium nitrate was applied 60 days after transplanting. Ninety-six plants were randomly harvested from each of the eight areas (four from each system) of this experiment.

\section{Production of minimally processed lettuce}

Heads of Iceberg lettuce were minimally processed using proper processing equipment and sanitation. The working area was divided into "clean" and "dirty". In the dirty area, the income lettuce was separated by system, maintaining a continued flow in the unit. Each lettuce head 
was washed by hand with cold $\left(15^{\circ} \mathrm{C}\right)$ potable water for 3 minutes to remove soil and organic residues. Then, the produce was moved to the clean area in sanitised harvesting crates and minimally processed according to Wiley (1994).

Lettuce leaves were stripped off and only light green leaves were selected for processing. Leaves were treated for 3 min with a free chlorine solution $\left(100 \mathrm{mg} \mathrm{L}^{-1}\right)$ at 1 to $4^{\circ} \mathrm{C}$ (IBD, 1995). The excess chlorine was removed with cold water $\left(4^{\circ} \mathrm{C}\right)$ and leaves were centrifuged for 45 seconds at $450 \mathrm{rpm}$.

Lettuce leaves (three per 30 x $30 \mathrm{~cm}$ bag, 5 L volume) were packaged in low density polyethylene bags (LDPE $-0.910-0.940 \mathrm{~g} \mathrm{~cm}^{-3}$ ) and weighed with a semi-analytical scale. Package sealing was carried out in normal atmospheric conditions, using a Turbovac 450-S® sealer. The packaged produce was stored in a vertical refrigerator and monitored by a thermohygrograph, keeping the storage temperature around $4{ }^{\circ} \mathrm{C}$ and the relative humidity at $80 \%$.

\section{Oxygen and carbon dioxide monitoring}

The variation of the oxygen and carbon dioxide inside the bags with lettuce leaves was evaluated by gas chromatography at different storage times (3, 6, 8, 10 and 12 days of storage) for both cultivation systems. Evaluations were performed in three repetitions (three bags of each treatment, for each storage time). Analysis were carried out using a gas chromatograph Shimadzu GC-8A®, with two Porapak Q ${ }^{\circledR}$ columns (8 m length, 6.35 $\mathrm{mm}$ diameter) and a thermal conductivity detector (TCD). Fifty microliters of packaging gas was injected into the chromatograph. Helium $100 \%$ was used as carrier gas, at $28 \mathrm{~mL}$ per second. The initial oven temperature was held at $20^{\circ} \mathrm{C}$ to separate nitrogen and oxygen, then, after oxygen evaluation, increased to $180^{\circ} \mathrm{C}$ and held at this temperature to the end of the analysis for each sample.

Oxygen and carbon dioxide concentrations obtained by gas chromatography were calibrated using atmospheric air concentration as standard, in an enough time to pass all atmospheric gases. The correction factor for the evaluation of gas concentration was established by calculating the molar fraction of each product from integrated surfaces (Chromatogram peak areas, using a Shimadzu ${ }^{\circledR}$ integrator), according to Equation 1, using nitrogen gas, as it is not involved in the respiratory process.

\section{$\mathrm{X}_{\mathrm{i}} / \mathrm{N}_{2=} \mathrm{X}_{\mathrm{i}} / \mathrm{XN}_{2} \cdot \mathrm{SN}_{2} / \mathrm{S}_{\mathrm{i}}$ (Equation 1$)$}

where: $\mathrm{X}_{\mathrm{i}} / \mathrm{N}_{2}=$ correction factor for the i product related to $\mathrm{N}_{2} ; \mathrm{X}_{\mathrm{i}}=$ molar fraction of the i product; $\mathrm{XN}_{2}=$ molar fraction of the $\mathrm{N}_{2}$ product; $\mathrm{SN}_{2}=\mathrm{N}_{2}$ integrated surfaces; $\mathrm{S}_{\mathrm{i}}=$ integrated surfaces of the i product.

\section{Dry matter determination}

The gravimetric determination of the dry matter in iceberg lettuce was performed at 3, 6, 8, 10, 12 and 14 days of storage, with five repetitions for both cultivation systems, according to AOAC methodology, number 934.01 (AOAC, 1998). Five discs were excised from the leaf blade of each sample, including central and secondary veins, because of the existent variations among leaf shapes and to fit into a Petri dish. The average area of each circular cutting was $5.725 \mathrm{~cm}^{2}$. Each group of five discs was dried in a Petri dish and the final weight was related to the initial weight in $g$ $100 \mathrm{~g}^{-1}$ of fresh lettuce. Evaluation of dry matter did not consider zero time, immediately after the conditioning of lettuce leaves, aiming to re-establish the internal and external equilibrium in the bags, which resulted from film permeability to water vapor (Kader et al., 1989).

\section{Experimental design}

The experiment was arranged as a $2 \times 7$ factorial in a randomized complete block design and five repetitions. Factor A consisted of the cultivation system: A1 - organic cultivation system and A2 - conventional cultivation system. Factor B had seven levels: B1 - day zero, B2 - 3 days, B3 - 6 days, B4 - 8 days, B5 - 10 days, B6 - 12 days and B7 - 14 days). Samples consisted of a pool of three plants that were taken from each of the four areas plots of both systems. Five sub-samples were extracted at random from each pool, each consisting of three lettuce leaves, that is, two systems $\mathrm{x}$ seven exposition times $\mathrm{x}$ five repetitions, making 70 experimental units. Data were examined by analysis of variance and $\mathrm{F}$ test significance, regression analysis was performed and the equation models were chosen depending on the phenomena under study.

\section{RESULTS AND DISCUSSION}

All conditions of minimal processing applied to organic and conventional lettuces were similar, therefore this discussion will focus on the respiration performance of the plants grown under these two cultivation systems. Oxygen $\left(\mathrm{O}_{2}\right)$ consumption and carbon dioxide $\left(\mathrm{CO}_{2}\right)$ production followed the typical tendency expressed by the senescence biological model (Chitarra \& Chitarra, 2005). The $\mathrm{O}_{2}$ concentration decreased and the $\mathrm{CO}_{2}$ increased (Figure 1) during the storage time of lettuce leaves in LDPE bags. These results are in agreement with the reports by Lee et al. (1991) and Del Nobile et al. (2006).

Reduction in oxygen and increase in carbon dioxide concentrations create a pressure gradient which causes oxygen to enter and carbon dioxide to be released from the package. At the beginning of the process, the gradient is small and the flux across the bag is insufficient to replace 


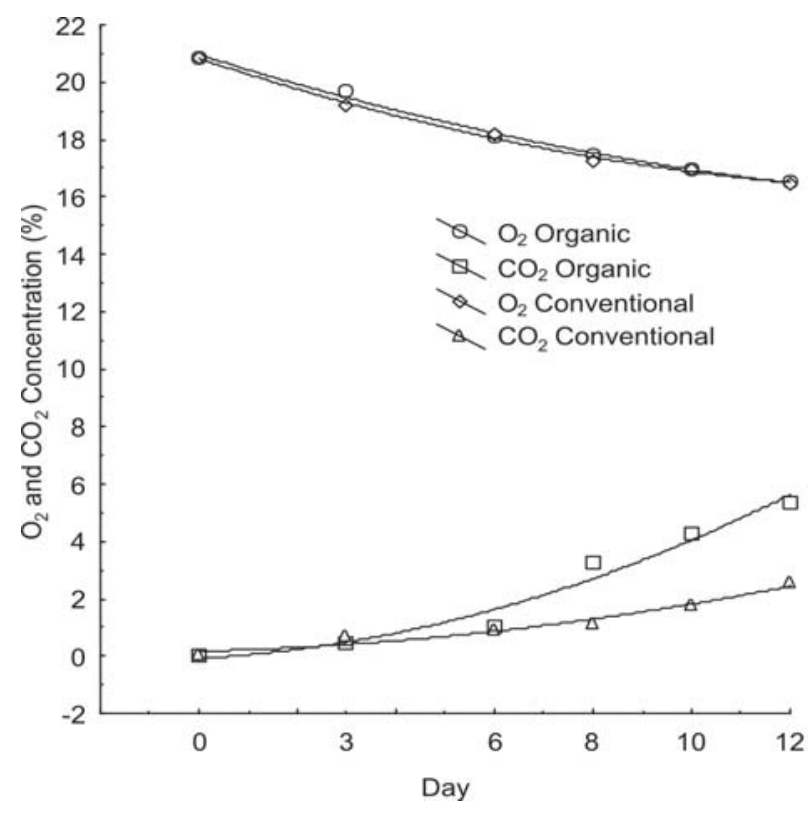

Figure 1. Time course during storage of headspace gas composition of minimally processed iceberg lettuce, in organic and conventional cultivation systems $\left(1 \mathrm{~atm}, 4^{\circ} \mathrm{C}\right)$ packaged in low density polyethylene (LDPE) bags.

the consumed oxygen or to transfer all the carbon dioxide generated. Inside the bag, the concentrations of oxygen decreases and carbon dioxide increases, creating a modified atmosphere (Wiley, 1994).

The carbon dioxide analysis showed differences $(\mathrm{p}<$ 0.05 ) between the cultivation systems, regarding shelftime exposure and interactions. The results of the regression analysis showed a quadratic significant effect, indicating that the organic and conventional systems of cultivation produced different effects on carbon dioxide concentrations. The coefficients of determination $\left(R^{2}\right)$ were 0.9673 and 0.9592 for organic and conventional systems, (Figure 2).The lettuce grown on the organic system yielded a higher carbon dioxide concentration, probably due to the larger amount of dry matter compared with the conventional system. This result helps to maintain good sensorial characteristics, increasing the shelf life of the minimally-processed iceberg lettuce (Mello et al., 2003).

The respiratory quotient (RQ) of conventionally cultivated lettuce was higher than that of the organically cultivated lettuce in the first days of storage. However, it decreased by day 8 of exposure (Figure 3). On the other hand, the organic lettuce had an increasing respiratory rate throughout the experimental period. A higher availability of low-molecular-weight energetic substrates may explain the higher respiratory rate of the conventional lettuce during the first few days of exposure. The organic lettuce could contain a higher reserve of high-molecularweight substances which may also contribute to the observed increasing respiratory rate.

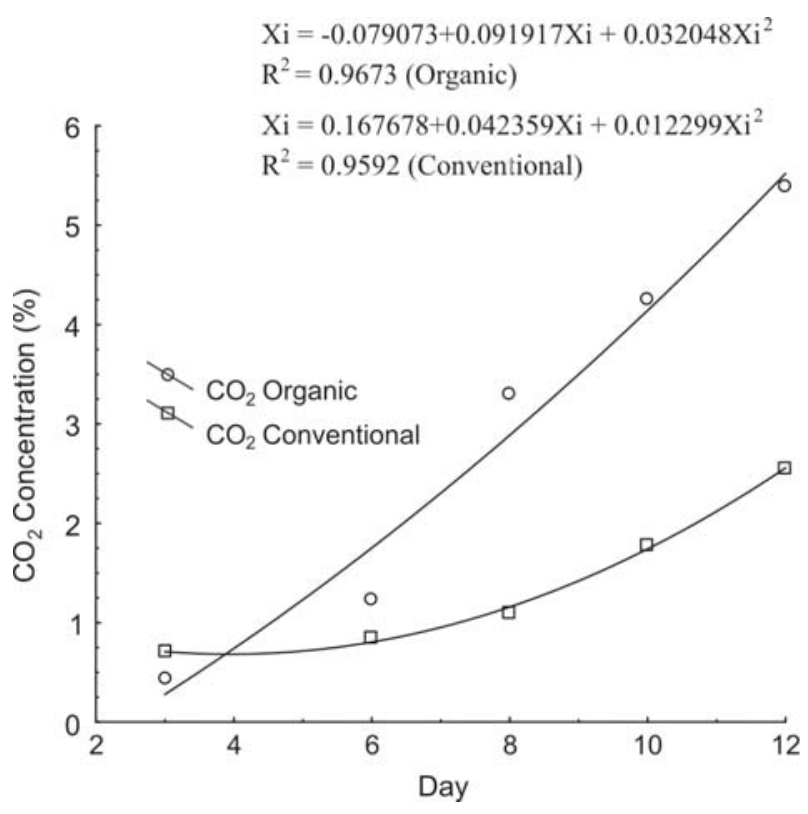

Figure 2. Time course during storage of headspace carbon dioxide of minimally processed iceberg lettuce, in organic and conventional cultivation systems $\left(1 \mathrm{~atm}, 4^{\circ} \mathrm{C}\right)$ packaged in low density polyethylene (LDPE) bags.

The ratio of the amount of $\mathrm{CO}_{2}$ released to the amount of $\mathrm{O}_{2}$ consumed is the respiratory quotient (RQ) and it is always around 1.0, when the oxidized substrates are carbohydrates. However, an RQ lower than 1.0 indicates that other substrates are being oxidized, for example, substrates with a $\mathrm{C} / \mathrm{O}$ ratio lower than hexoses. In this case incomplete oxidation is taking place (an interruption at the level of intermediary compounds of the Kreb's cycle) and the $\mathrm{CO}_{2}$ produced is being used in synthesis processes, such as pyruvate carboxylation for oxaloacetic acid production. An RQ greater than 1.0 indicates that organic acids are being oxidized (Ferri, 1985).

$\mathrm{RQ}$ is related with the nature of the chemical composition of the plant and with the nature of the organic substrate used in the respiratory process (Lencki, 2004). The RQ analysis shows the tendency to reach the unit value (1.0) (equilibrium) is higher in organic lettuce but significantly lower in conventional lettuce, which could represent different compositions of these products (Figure 4). Thus, the difference in RQ between the two lettuce cultivation systems indicate differences in the composition of these products (Chitarra \& Chitarra, 2005).

The comparison of the two estimated equations shows that in the conventional system, the negative element is the linear term bXi $=-0.0141412524 \mathrm{Xi}$, which increases with the storage time, while in the organic system, the negative element is the intercept a $=-0.438517$, which remains constant as $\mathrm{Xi}$ (storage time) increases. Therefore, the respiratory activity in the conventionally grown lettuce affects the linear term, which also represents the respiratory intensity by a lower 
production of carbon dioxide, and hence this lettuce probably presents a lower content of carbohydrates than the organically grown lettuce resulting in the differences between the two equations. Considering that the same kind of package and the same conditions of storage were used, the atmospheric composition inside the package can be attributed to the cultivation system.

The dry matter allowed the comparison of leaf structures of plants of the same age produced in both cultivation systems. Additionally, considering the water lost by the minimally processed lettuce during respiration and the determination of dry matter during the storage

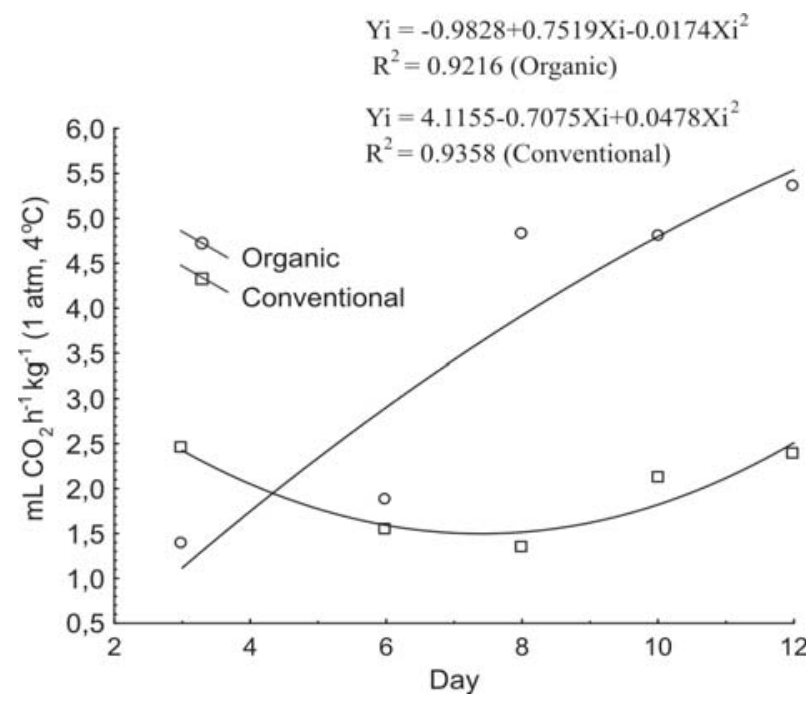

Figure 3. Respiratory rate as a function of time of minimallyprocessed iceberg lettuce, in organic and conventional cultivation systems $\left(1 \mathrm{~atm}, 4{ }^{\circ} \mathrm{C}\right)$ packaged in low density polyethylene (LDPE) bags.

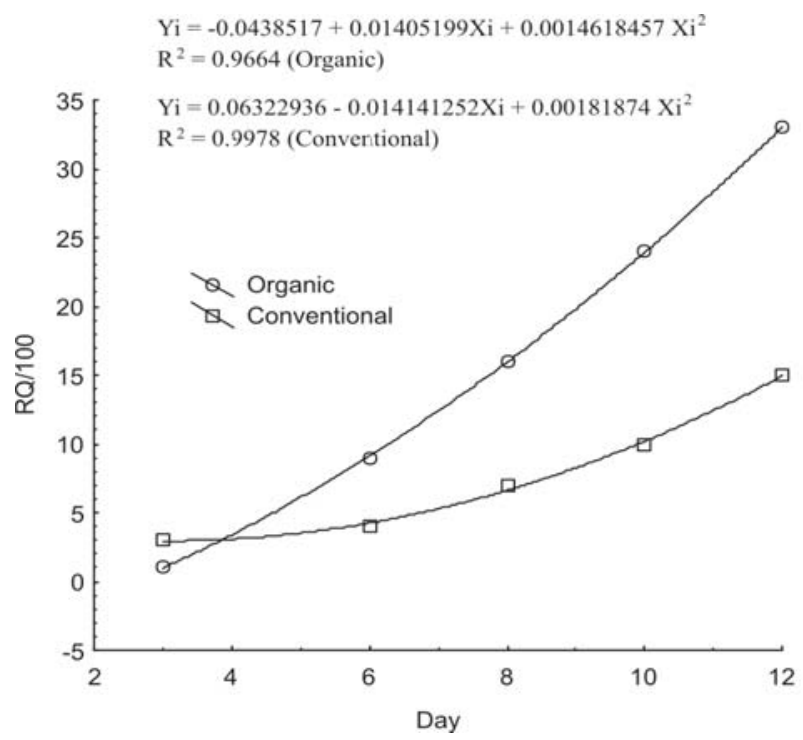

Figure 4. Respiratory quotient (RQ) as a function of time of minimally-processed iceberg lettuce, in organic and conventional cultivation systems $\left(1 \mathrm{~atm}, 4{ }^{\circ} \mathrm{C}\right)$ packaged in low density polyethylene (LDPE) bags. period, it was possible to establish a relationship between the shelf life and cultivation system.

A non-linear regression analysis for each system was carried out to study the performance of lettuce over time using the equation: $\mathrm{Yi}=\mathrm{aXi}^{\mathrm{b}}$ (Figure 5). $\mathrm{Xi}^{-0.267515}<\mathrm{Xi}^{-}$ ${ }^{0.413541}$ means that the matter released per day of storage was higher in the organically grown lettuce. The organic lettuce accumulated more dry matter than the conventional lettuce, thus presenting more mass to be released during the storage period.

Respiration is considered the best indicator of cellular metabolic activity and a reduction in its intensity decreases the overall metabolic rate of the plant. The application of the law of mass action to respiration, in which complete oxidation of carbohydrates produces $\mathrm{CO}_{2}$ and $\mathrm{H}_{2} \mathrm{O}$, suggests that the increase of $\mathrm{CO}_{2}$ and the reduction of $\mathrm{O}_{2}$ in the air could reduce the respiration rate with a positive effect on the extension of post-harvest conservation of horticultural products (Lana, 2000).

The stoichiometry of respiration reaction is the foundation of the respiratory performance of organic lettuce, and as expected, it was found found a greater water release in this lettuce, due to the higher RQ. This performance gives an indication of the substrate nature of the respiration process in lettuce from both cultivation systems, as well as the water-binding compounds present in the leaf structure, polysaccharides such as pectin and hemicelluloses. The presence of solids in cellular tissues would likely lead to a reduction in $\mathrm{CO}_{2}$ solubility and a slightly higher respiratory quotient than those predicted from literature (Lencki, 2004).

Organic lettuce, in which a higher RQ was recorded, showed a larger content of dry matter. This may suggest a different composition of lettuce cultivated in the organic system.

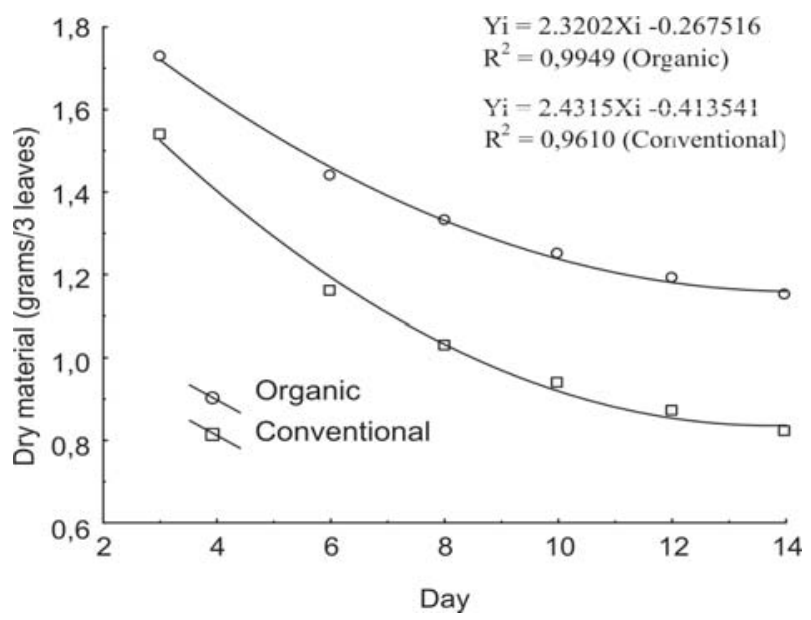

Figure 5. Time course during storage for dry matter of minimally-processed iceberg lettuce, in organic and conventional cultivation systems $\left(1 \mathrm{~atm}, 4^{\circ} \mathrm{C}\right)$ packaged in low density polyethylene (LDPE) bags. 


\section{CONCLUSIONS}

The type of cultivation system affected the respiration of iceberg lettuce.

Carbon dioxide production was higher in organic lettuce compared with conventional lettuce, suggesting a difference in the nature of the substrate.

The performance of oxygen and carbon dioxide dynamics within the packages can be attributed exclusively to the cultivation system.

\section{REFERENCES}

Ahvenainen R (1996) New approaches in improving the shelf life of minimally processed fruit and vegetables. Trends in Food Science \& Technology, 7:179-187.

Alzamora, SM, Tapia MS \& López-Malo (2000) Minimally processed fruits and vegetables. Gaithersburg, Maryland: Aspen Publishers.

Association of Official Analytical Chemistry-AOAC (1998) Official Methods of Analysis. 16ed. Arlington: AOAC International.

Baur S, Klaiber R, Wei H, Hammes WP \& Carle R (2005) Effect of temperature and chlorination of pre-washing water on shelflife and physiological properties of ready-to-use iceberg lettuce. Innovative Food Science \& Emerging Technologies, 6:171-182.

Chitarra MIF \& Chitarra AB (2005) Pós-colheita de frutas e hortaliças: fisiologia e manuseio. Lavras: ESAL, FAEPE, 783 p.

Del Nobile MA, Baiano A, Benedetto A \& Massignan L (2006) Respiration rate of minimally processed lettuce as affected by packaging. Journal of Food Engineering, 74: 60-69.

EPAGRI. (1997) A Cultura da Alface. Florianópolis, 24p. Non published work.

Ferri MG (1985) Fisiologia vegetal. 2. ed. São Paulo. Editora Pedagógica e Universitária Ltda. V.1. 350 p.

Instituto Biodinâmico - IBD (1995) Diretrizes para os padrões de qualidade biodinâmico, deméter e orgânico. 5.ed. Botucatu, 26p.

Kader AA, Zagory D \& Kerbel EL (1989) Modified atmosphere packaging of fruits and vegetables. Critical Reviews in Food Science and Nutrition, 28:1-30.

Lana MM Atmosfera modificada e controlada (2000) Aplicação na conservação de produtos hortícolas. Brasília: Embrapa Hortaliças, 34p.

Lee DS, Haggar PE, Lee J \& Yam KL (1991) Model for fresh produce respiration in modified atmospheres based on principles of enzyme kinetics. Journal of Food Science, 56:1580-1585.

Lencki RW (2004) Comparison of unsteady- and steady-state methods for produce respiration rate determination. 2 . Reexamination of the literature. Postharvest Biology and Technology, 31: 239-250.

Mattos LM, Moretti CL, Chitarra AB \& Chitarra MIF (2008) Atividade respiratória e evolução de etileno em alface crespa minimamente processada armazenada sob duas temperaturas. Ciência Agrotécnica, 32:1985-1990.

Mello JC, Dietrich R, Meinert EM, Teixeira E \& Amante ER (2003) Efeito do cultivo orgânico e convencional sobre a vida de prateleira de alface americana (Lactuca sativa L.) minimamente processada. Ciência e Tecnologia de Alimentos, 23:418426.
Suslow T (2007) Post harvest handling for organic crops. <http:/ /anrcatalog.ucdavis.edu/pdf/7254.pdf >, 15:37, may 2.

Wiley RC (1994). Minimally processed refrigerated fruits and vegetables. New York, Chapman \& Hall, 368p. 